\title{
Essay
}

\section{Health and economic benefits of an accelerated program of research to combat global infectious diseases}

\section{Global IDEA Scientific Advisory Committee}

ß See related article page 1199

$\mathrm{R}$ educing the burden of disease in developing countries is central to global economic development and security. ${ }^{1-3}$ Combatting infectious disease is crucial to improving prospects for the poor and preventing the rapid spread of infections in an interdependent world. The outbreak of SARS in the spring of 2003 led to a major rethinking of our preparedness to fight infectious diseases domestically. ${ }^{4}$ Less appreciated is the link between global and domestic control of infectious diseases and the role that individual countries can play in combatting infectious diseases worldwide through control and research.

In this article we provide the rationale for an accelerated program for infectious disease research. We first review the role scientific research has played in the historic rates of decline in infectious disease mortality during the 20th century. We identify current infectious disease priorities and research gaps. Next we discuss the economic benefits of disease control, including the likely benefits of accelerated research. Finally, we provide the broad contours of an accelerated Canadian response to global infectious diseases.

\section{The contribution of scientific research}

The 20th century saw extraordinary declines in premature mortality in both developed and developing countries. Advances in science contributed greatly to reductions in infectious disease through better control over vaccinepreventable disease, advances in antibiotic therapies and their delivery, promising new diagnostic technologies and, to a more limited extent, new technologies to fight diseases at the molecular level.

In 1900 life expectancy at birth in developed countries was about 40 years and, in most developing countries, below 20 years. By 2000, life expectancy had nearly doubled in Canada and had tripled (or more) in developing countries. ${ }^{5}$ Much of these gains occurred in recent decades: between 1960 and 1995 alone, life expectancy in low-income countries improved by 22 years, as opposed to 9 years in developed countries. As a global average, the under-five mortality rate declined from $16 \%$ in the 1960 s to $8 \%$ in the 1990s. ${ }^{6}$ Whereas some have attributed these gains to economic growth, overall the magnitude and rate of decline in premature mortality in both developed and developing countries in recent years have been much greater than can be directly accounted for by growth in income levels. ${ }^{7-10}$ These gains have been more rapid than the equivalent decline in mortality that occurred in the developed world during the late 19th and early 20th centuries and have affected the lives of far more people.

Consider the declines in infectious disease (Table 1). Improved living conditions paired with the use of vaccines and antimicrobial agents and the ability to identify new pathogens have been central to the more than $90 \%$ reduction in communicable disease mortality in Canada and the United States. ${ }^{11}$ Today more than 30 common infectious diseases are controllable with vaccines. In 1970 perhaps only $5 \%$ of the world's children under 5 were vaccinated against measles, tetanus, pertussis, diphtheria and polio. By 1990 the Expanded Programme on Immunization had raised this proportion to about $75 \%$, saving over 3 million lives a year. ${ }^{12}$ Diarrhea-related deaths among children have fallen by several million a year, partly as a result of the development of oral rehydration therapy, much of which was the result of work in population research laboratories in Bangladesh. The most spectacular success in immunization is the World Health Organization's campaign against smallpox, which culminated in the eradication of smallpox in human populations by 1979. The WHO is now engaged in an ongoing campaign to eradicate poliomyelitis by 2005 .

Before 1950 the only major antibiotics were sulfonamides and penicillin. Subsequently there has been remarkable growth in the development and use of agents effective against bacteria, fungi, viruses, protozoa and helminths. The delivery of a combination of antituberculosis drugs with direct observation (or DOTS) has lowered casefatality rates from well over $60 \%$ to $5 \%$ and has decreased transmission. The percentage of the world's tuberculosis cases treated with DOTS has risen from about 1 in 10 in 1990 to about 1 in 3 today. ${ }^{13}$ Development of effective antiviral agents has lagged behind, partly because viruses mutate rapidly. Research into HIV/AIDS and related diseases is providing a better understanding of the mechanisms of the self-copying or assembly function of viruses and retroviruses and is accelerating the development of antiviral agents. ${ }^{8}$ Large-scale randomized trials have increasingly been used to establish widely practicable therapies, espe- 
cially where modest but important treatment benefits are sought. ${ }^{14}$ Finally, advances in computing and statistics have led to more robust mathematical models of infectious disease spread..$^{15}$

A recent chapter is the development of molecular biology and recombinant DNA technology in the second half of the 20th century. The benefits of genetic technology to global health are as yet limited but could be extraordinary ${ }^{16,17}$ (see text box). Already, genomics is being used in the response to infectious disease outbreaks. The sequencing of infectious agents and vectors can assist in understanding drug and insecticide resistance and is key to the development of new drugs and vaccines. ${ }^{18,19}$ Genetic sequencing is also being applied to diagnostics: the remarkable speed in identifying a new coronavirus and its different subtypes as the causative agent of SARS $^{20}$ is but one example of the value of DNA-based methods of research.

\section{Current challenges}

The lion's share of global disease burdens is borne by poor countries. HIV/AIDS, tuberculosis and malaria account for some 6 million deaths yearly worldwide (Table 2 ), and child deaths - largely from other infective diseases - account for another 11 million. Infectious diseases account for about one-third of deaths worldwide (about 17 million deaths, a number equivalent to half of Canada's population) and over two-thirds of deaths in Africa.

For each priority disease, a combination of greatly expanded programs to implement existing interventions is required along with focused research to identify new interventions and better ways to achieve high coverage with existing interventions. Table 3 lists current coverage of the most effective interventions and examples of high-priority research needs. ${ }^{1,3}$

The dominant challenge for nearly all these populations at the beginning of the 21 st century is to curb the spread of HIV-1 infection. HIV/AIDS alone accounts for some 3 million deaths a year and is well on its way to exacting an accumulated toll of several hundreds of millions. Nearly 5 million new HIV-1 infections occur every year, and it appears unlikely that even the recently launched WHO program of placing 3 million people on life-prolonging, antiretroviral therapy by 2005 will markedly reduce new infections. Peer-based interventions for education and to promote condom use have been documented to reduce transmission in high-risk populations by up to $80 \%^{15,21,22}$ but are not commonly implemented because of low levels of funding as well as lingering debate about the role of sex work in driving infection rates. There remains considerable uncertainty about the role of other factors that might determine HIV-1 transmission, such as sexually transmitted coinfections and male circumcision. ${ }^{21}$ Similarly, other preventive strategies such as female-controlled microbicides

\section{Top 10 biotechnologies for the global poor}

1. Molecular technologies for affordable, simple diagnosis of infectious diseases

2. Recombinant technologies to develop vaccines against infectious diseases

3. Technologies for more efficient drug and vaccine delivery systems

4. Technologies for environmental improvement (sanitation, clean water, bioremediation)

5. Sequencing pathogen genomes to understand their biology and to identify new antimicrobials

6. Female-controlled protection against sexually transmitted diseases, both with and without contraceptive effect

7. Bioinformatics to identify drug targets and to examine pathogen-host interactions

8. Genetically modified crops with increased nutrients to counter specific deficiencies

9. Recombinant technology to make therapeutic products (e.g., insulin, interferons) more affordable

10. Combinatorial chemistry for drug discovery

Reproduced, with permission, from Daar et al. ${ }^{16}$

Table 1: Examples of the contribution of scientific research to declines in infectious disease mortality in the 20th century

\begin{tabular}{|c|c|c|c|}
\hline \multirow[b]{2}{*}{ Condition and intervention } & \multicolumn{2}{|c|}{ Annual no. of deaths } & \multirow[b]{2}{*}{ Reference } \\
\hline & $\begin{array}{l}\text { Before intervention } \\
\text { (reference year), } \\
\text { thousands }\end{array}$ & $\begin{array}{l}\text { After intervention } \\
\text { (reference year), } \\
\text { thousands }\end{array}$ & \\
\hline $\begin{array}{l}\text { Polio, diphtheria, pertussis, tetanus and } \\
\text { measles - immunization programs }\end{array}$ & 5200 (1980) & $1400(2001)$ & 12 \\
\hline Small pox - eradication campaign & ３000 (1950) & $0(1979)$ & 31 \\
\hline Diarrhea — oral rehydration therapy & ４600 (1980) & $1600(2001)$ & 3 \\
\hline $\begin{array}{l}\text { Malaria outside Africa - residual } \\
\text { indoor spraying and acute management }\end{array}$ & 3500 (1930) & $<50(1990)$ & 45 \\
\hline $\begin{array}{l}\text { Malaria in Africa - limited use of } \\
\text { residual indoor spraying and acute } \\
\text { management }\end{array}$ & 300 (1930) & 1000 (1990) & 45 \\
\hline
\end{tabular}


are of unknown efficacy. Some of these could be quite powerful: for example, mathematical modelling predicts that, over 3 years, 2.5 million HIV-1 infections could be averted if a microbicide that is $60 \%$ effective against HIV-1 were used by $20 \%$ of women in half of all sexual acts that do not involve a condom. ${ }^{23}$

Against this background of endemic disease, new threats loom. The SARS outbreaks in Canada, China and Hong Kong were a potent reminder of the danger of novel organisms. More than 30 "new" infectious agents have been identified since 1970, including Ebola, hepatitis C and West Nile virus. There have been consistent projections that a major pandemic of influenza is inevitable ${ }^{24}$ and that this may well lead to several million deaths worldwide.

Finally, antimicrobial resistance appears to be growing and is fuelled by indiscriminate use of antibiotics in the community, in hospitals and in agriculture. ${ }^{25}$ Resistance to antiviral agents is also increasing. ${ }^{26}$ In the United States, the number of patients newly infected with drug-resistant HIV-1 increased from $3 \%$ in 1995 to $12 \%$ in 2000 . In India, primary HIV-1 drug resistance is estimated at $10 \%$ in one clinic in Mumbai, ${ }^{27}$ and it is likely that antiretroviral drug resistance is common worldwide. Expanding antiviral resistance may threaten currently effective interventions to reduce mother-to-child HIV-1 transmission..$^{28}$ Similarly, chloroquine-, quinine- and mefloquine-resistant malaria is now common. ${ }^{29}$

\section{Costs of disease, benefits of control}

Although the health benefits of scientific advances are abundant, recent evidence also suggests that disease control has had a major impact on economic growth. According to the Commission on Macroeconomics and Health ${ }^{2}(\mathrm{CMH})$, each $10 \%$ increase in life expectancy at birth is associated with a rise in economic growth of about $0.3 \%-0.4 \%$ per year, other growth factors being constant. Thus the difference in annual economic growth accounted for by differences in life expectancy between a typical high-income country (around 77 years) and a typical least-developed country (around 49 years) is about $1.6 \%$ per year, which cumulates over time. Conversely, reductions in life expectancy accelerate economic decline. In sub-Saharan Africa, the average life span has been cut short by years or decades in countries hard hit by HIV/AIDS, and overall life expectancy has fallen to 46 years. There was a decline in income of $1.7 \%$ per year between 1990 and 2000. By these standards, the economic cost of the AIDS epidemic is estimated to be $15 \%$ of sub-Saharan Africa's GDP in $2000 .{ }^{30}$

The economic returns for controlling endemic and emerging diseases through mortality reduction, creating a more productive workforce and increasing economic investment are enormous (and may well have been underestimated in the past). For example, the $\mathrm{CMH}$ estimated that even a modest program to control major diseases globally would generate some $\$ 500$ billion per year from 2015 to $2020 .^{2}$ Smallpox eradication cost some $\$ 300$ million but generated over $\$ 27$ billion in cost savings over a 20 -year period. ${ }^{31}$ The rate of return for HIV prevention in Thailand is estimated at $12 \%$ to $32 \%$ annually. In the absence of prevention measures, AIDS in Thailand would have reduced the GDP by $15 \%$ by $2015 .{ }^{32}$ Control of HIV-1 and malaria were recently judged by a global panel to provide rates of return far greater than most other development priorities, such as water and sanitation or efforts to improve governance..$^{33}$ An outbreak of plague in India in 1994 may have cost several billion dollars in forgone travel and other retail revenue, but quick action against a smaller 2001 outbreak probably saved several billions of dollars. ${ }^{34}$

\section{Economic returns from investments in science}

What, then, is the role of research in global health aid? Organization and funding of control programs has received much attention recently, including the launch of Global Stop TB, the WHO's " 3 by 5 " effort to place 3 million people with HIV-1 infection on antiretroviral therapy by 2005, the Roll Back Malaria program, polio eradication and efforts to expand routine immunization. For each area, research remains central to identifying new tools and evaluat-

Table 2: Specific causes of death worldwide, $2001^{46}$

\begin{tabular}{|c|c|c|c|c|c|c|}
\hline \multirow[b]{2}{*}{ Cause } & \multicolumn{3}{|c|}{ Age, $y r$; no. of deaths, thousands } & \multicolumn{3}{|c|}{ Age, yr; \% of deaths } \\
\hline & $\leq 14$ & $\geq 15$ & Total & $\leq 14$ & $\geq 15$ & Total \\
\hline HIV/AIDS & 442 & 2133 & 2575 & 3.7 & 13.5 & 4.6 \\
\hline Tuberculosis & 73 & 1533 & 1606 & 0.6 & 9.7 & 2.9 \\
\hline Malaria & 1103 & 106 & 1209 & 9.1 & 0.7 & 2.1 \\
\hline $\begin{array}{l}\text { Vaccine-preventable } \\
\text { childhood diseases* }\end{array}$ & 1382 & 256 & 1638 & 11.4 & 1.6 & 2.9 \\
\hline $\begin{array}{l}\text { Lower respiratory tract } \\
\text { infections }\end{array}$ & 2045 & 1710 & 3755 & 16.9 & 10.8 & 6.7 \\
\hline Diarrhea & 1607 & 177 & 1784 & 13.3 & 1.1 & 3.2 \\
\hline All causes & 12102 & 15768 & 56268 & 100.0 & 100.0 & 100.0 \\
\hline
\end{tabular}

*Includes pertussis, poliomyelitis, diphtheria, measles (which is close to half of all deaths), tetanus, meningitis and hepatitis B. 
ing existing ones. In the 1990s it was estimated that, even though $85 \%$ of the global burden of disability and premature mortality occurred in the developing world, less than $4 \%$ of global research funding was devoted to communicable, maternal, perinatal and nutritional disorders, which constitute the main burden of disease in developing countries. ${ }^{35}$ However, the scale of research response appears to fall short of what is required, especially given the evidence that the economic and social returns on research are likely to be enormous. By one estimate, even in the United States (which has the largest percentage of spending on health research and development), research spending could rise 10fold and still be below optimal. ${ }^{36}$ Recent calls have been made for a new effort to accelerate HIV-1 vaccine development. ${ }^{37}$ The Bill and Melinda Gates Foundation has issued a US\$200 million call for scientific efforts to tackle some of the most significant research bottlenecks. ${ }^{38}$ A Global Forum on Health Research has been created as a meeting ground for health research. ${ }^{35}$
Estimates of Canadian research funding directed at global diseases are difficult to obtain, although it is clear that the amounts from the Canadian Institutes of Health Research (CIHR), Health Canada and other sources are small. A notable exception is a contribution of $\$ 50$ million to the International AIDS Vaccine Initiative. CIHR has shown innovation in strategies for battling SARS, such as the Canadian SARS Research Consortium and Canadian Rapid Research Response Team. ${ }^{39}$ Other efforts include the launch of the Canadian Coalition on Global Health Research (www .cghrc.ca/cghrc.html) to help disseminate research findings, and a new focus on global health by this journal. ${ }^{40}$ However, funding for research on infectious disease remains almost entirely focused on domestic priorities, and CIHR administrative and peer-review rules limit major research projects in developing countries. In short, the scale of the response is entirely incommensurate with the scope of the problem.

What might be the return from an increased program of global infectious disease research? Consider the following.

Table 3: Current and target coverage of most effective interventions and specific research needs for priority diseases

\begin{tabular}{|c|c|c|c|c|}
\hline \multirow[b]{2}{*}{ Conditions and interventions } & \multirow{2}{*}{$\begin{array}{l}\text { Directly } \\
\text { attributable deaths } \\
\text { in 2001, thousands }\end{array}$} & \multicolumn{2}{|c|}{ Coverage of interventions, $\%$} & \multirow[b]{2}{*}{ Priority research needs } \\
\hline & & Current & Goal by 2015 & \\
\hline $\begin{array}{l}\text { Polio, diphtheria, pertussis, tetanus, } \\
\text { hepatitis } B, \text { measles and Haemophilus } \\
\text { influenzae type } b \text { (Hib) - immunization } \\
\text { programs }\end{array}$ & 1637 & $75^{*}$ & 90 & $\begin{array}{l}\text { Add new antigens (Streptococcus } \\
\text { pneumoniae, Hib), better delivery } \\
\text { mechanisms }\end{array}$ \\
\hline $\begin{array}{l}\text { Acute respiratory tract illnesses - } \\
\text { treatment of childhood illnesses }\end{array}$ & 2045 & 59 & 80 & $\begin{array}{l}\text { Add } S \text {. pneumoniae antigen to } \\
\text { immunization, low-cost diagnostics }\end{array}$ \\
\hline $\begin{array}{l}\text { Diarrhea - treatment of childhood } \\
\text { illnesses }\end{array}$ & 1607 & 52 & 80 & Vaccines against rotavirus, Shigella \\
\hline $\begin{array}{l}\text { Malaria - insecticide-treated nets and } \\
\text { residual indoor spraying }\end{array}$ & 1208 & 2 & 50 & Newer insecticides, malaria vaccines \\
\hline Malaria — treatment of clinical episodes & 1208 & 31 & 60 & New antimalarials, malaria vaccines \\
\hline $\begin{array}{l}\text { Tuberculosis - short-course treatment of } \\
\text { smear-positive and smear-negative } \\
\text { patients }\end{array}$ & 1606 & 44 & 70 & $\begin{array}{l}\text { New antimicrobials, correlates of } \\
\text { continued latency and conversion to } \\
\text { active disease, tuberculosis vaccine, } \\
\text { diagnostics }\end{array}$ \\
\hline $\begin{array}{l}\text { HIV/AIDS and STDS - interventions to } \\
\text { decrease sexual transmission }\end{array}$ & 2576 & $10-20$ & 80 & $\begin{array}{l}\text { Microbicides, male circumcision, role } \\
\text { of core transmitter groups and } \\
\text { coinfections in transmission, HIV-1 } \\
\text { vaccines }\end{array}$ \\
\hline HIVIAIDS - antiretroviral therapy (ARV) & 2576 & $<5$ & 65 & $\begin{array}{l}\text { Population impact of ARV, micro-ARV, } \\
\text { newer combinations, role of } \\
\text { coinfections, low-cost delivery } \\
\text { methods, HIV-1 vaccines }\end{array}$ \\
\hline $\begin{array}{l}\text { Rapidly spreading respiratory viruses: } \\
\text { SARS }\end{array}$ & $<1$ & NA & NA & $\begin{array}{l}\text { SARS vaccine, antiviral agents, } \\
\text { epidemiological patterns }\end{array}$ \\
\hline $\begin{array}{l}\text { Rapidly spreading respiratory viruses: } \\
\text { influenza }\end{array}$ & 250-500† & NA & NA & $\begin{array}{l}\text { Rapid response to pandemic strains, } \\
\text { surveillance of antigenic shift, faster } \\
\text { development of vaccines }\end{array}$ \\
\hline Drug resistance & Unknown & NA & NA & $\begin{array}{l}\text { Monitoring of resistance patterns, } \\
\text { genetic correlates of drug resistance, } \\
\text { strategies to reduce resistance }\end{array}$ \\
\hline
\end{tabular}

ote: $\mathrm{NA}=$ not applicable.

*Excludes hepatitis B and Hib; current coverage is $68 \%$ for measles.

†Annual and not pandemic cases.

Source: Global IDEA Scientific Advisory Committee and references 1, 3, 7, 8, 16, 17, 21, 29, 35, 37, 38 and 46. 
The $\mathrm{CMH}^{2}$ estimates that funding of about US $\$ 200$ billion over the next decade or so might well reduce premature deaths by about 8 to 10 million annually (and some 300 million disability-adjusted life-years) and generate annual economic returns of over $\$ 186$ billion. If research on new tools (most importantly, methods to decrease HIV-1 transmission) costs even $1 \%$ of the total (about $\$ 2$ billion over 10 years), even a modest $5 \%$ increase in lives saved would result in annual returns of about $\$ 9$ billion. Thus, improved research is likely to greatly enhance overall effectiveness of global health aid. Similar reviews of US data suggest a 4 - to 30 -fold return on research expenditures. ${ }^{41}$

\section{An accelerated Canadian response}

We suggest 3 reasons why Canada is perhaps better placed than most countries to take forward an accelerated program on global infectious disease research.

First, Canada's standing with fellow nations is high. The Canadian government has shown leadership in the past, especially on peacekeeping and the ban on landmines. Although Canada's infectious disease spending is unlikely to reach that of the United States per capita, the political and administrative constraints of US funding are less prevalent in Canada. For example, partly because of public pressure, much of US infectious disease funding is focusing on the domestic threat of bioterrorism rather than on global infectious diseases. Canada is not so constrained; indeed, the Speech from the Throne of February 2002 called for directing $5 \%$ of domestic research and development (which totals about $\$ 20$ billion) toward global environmental and health concerns. The main constraint in Canada is funding. Overall, aid fell by over a third in the 1990s, and Canadian aid is about half of the stated goal of $0.7 \%$ of GNP. ${ }^{42}$ Canadian researchers already have a substantial network of researchers in developing countries in place, and strong links with the WHO and other global players exist. Thus, resources could be brought to bear quickly in developing countries.

Second, Canada has outstanding research capacity in the academic and private sectors. This includes departments of infectious disease and microbiology at every major university, as well as specific centres of excellence. Canada's traditional strength in biological sciences ${ }^{4}$ might well be expanded with epidemiology, mathematical modelling and other disciplines for more integrated responses to global diseases. It is worth noting that reasonable returns on investment by the private sector may well be possible, especially in generic drugs and vaccine production, where Canada has a reasonably good comparative advantage.

Third, the creation of the Public Health Agency of Canada (PHAC) and the strengthening of domestic laboratories and research groups creates an opportunity to apply the lessons learned from SARS, including the need for rapid mobilization and collaboration, to models for research and action against global diseases. In our view, the CPHA, while retaining a focus on rapid response against communicable diseases and combatting a limited set of priority diseases, would benefit from working globally: the best way to retain and engage researchers would be to adopt a focus on a handful of the major global diseases and apply their expertise to local disease control. For example, the experience gained from "ring" vaccination strategies in eradicating smallpox ${ }^{31}$ might help us in a bioterrorist attack, and the tracking of global resistance patterns against malaria has already informed local drug formulary and related choices, ${ }^{43}$ and understanding global evidence of correlates of acquired or innate immunity to HIV-1 will direct vaccine development. ${ }^{44}$

The timing and opportunity for a new accelerated program on infectious disease research is now. A consortium of infectious disease research scientists aligned with leaders in government and the private sector have formed a network called the Global Infectious Disease Evidence and Analyses (Global IDEA). The mission of Global IDEA is to strengthen Canada's scientific response against global infectious diseases. Over the next few months, Global IDEA will develop an implementation and funding blueprint focusing on 4-6 initiatives and ensure that these are widely circulated for input and debate (the blueprint will be posted at www.cghr.org/id). Candidate topics include: an accelerated program for HIV-1 vaccine research, paired with global initiatives; vaccines against SARS, influenza and related respiratory viruses; epidemiologic and mathematical tools for analyses and control of HIV-1, influenza and tuberculosis (including rapid response ability); host response to malaria and methods to lower malaria mortality; microbicides and diagnostics against major infections; and monitoring resistance to major drugs worldwide.

The notable features of each initiative would include: a focus on globally relevant priorities, such as methods to decrease HIV-1 transmission; a national and international scope to build on collaborative versus competitive networks; significant commitment of host institutions to pay for time of scientists engaged in the initiative; strong linkages and partnerships with local laboratories and scientists and with centres of excellence in Africa, East Asia and India; and private-sector partners to provide an additional dimension of product development, rapid mobilization and accountability. We do not envision any new bureaucracy to review or fund these proposals. Current mechanisms such as the Canadian Foundation for Innovation, CIHR, $\mathrm{Na}$ tional Centres for Excellence or a scaled-up Canadian International Development Association "Tier 1" competition could be used. In sum, accelerated research on the control of a small set of high-priority infectious diseases, most notably HIV/AIDS, tuberculosis, malaria and vaccinepreventable childhood infections, would generate enormous economic and social returns and strengthen ability to respond to local outbreaks and epidemics.

Competing interests: None declared.

Acknowledgement: We thank Mohan Kumar, Tina Daid and Priya Vasa for assistance. 


\section{References}

1. Jha P, Mills A, Hanson K, Kumaranayake L, Conteh L, Kurowski C, et al Improving the health of the global poor. Science 2002;295(5562):2036-9.

2. World Health Organization. Macroeconomics and bealth: investing in bealth for economic development. Report of the Commission on Macroeconomics and Health. Geneva: The Organization; 2002.

3. Jha P, Mills A. Improving health outcomes of the poor. Report of Working Group 5 of the Commission on Macroeconomics and Health. Geneva: World Health Organization; 2002

4. Naylor D, Basrur S, Bergeron MG, Brunham RC, Butler-Jones D, Dafoe G, et al; National Advisory Committee on SARS and Public Health. Learning from SARS: renewal of public health in Canada. Ottawa: Health Canada; 2003. Available: www.hc-sc.gc.ca/english/pdf/sars/sars-e.pdf (accessed 2004 Oct 13).

5. United Nations. Population division, revision of the world population estimates and projections. New York: UN; 1998.

6. Ahmad OB, Lopez AD, Inoue M. The decline in child mortality: a reappraisal. Bull World Health Organ 2000;78(10):1175-91.

7. World Health Organization. Investing in health research and development. Report of the Ad Hoc Committee on Health Research Relating to Future Intervention Options. Geneva: The Organization; 1996.

8. Weatherall D, Greenwood B, Chee HL, Wasi P. Science and technology for disease control: past, present, and future. In: Jamison DT, Alleyne GA, Breman JG, Claeson M, Jha P, et al, editors. Disease control priorities in developing countries. New York: Oxford University Press. In press.

9. Easterlin RA. How beneficent is the market? A look at the modern history of mortality. Eur Rev Econ Hist 1999;3:257-94.

10. Jamison D, Sachs JD. The economic benefits of disease control. In: Jamison DT, Alleyne GA, Breman JG, Claeson M, Jha P, et al. Disease control priorities in developing countries. New York: Oxford University Press. In press.

11. US Centers for Disease Control. Ten great public health achievements United States, 1900-1999. MMWR 1999;48(50):241-3. Available: www.cdc.gov/mmwr/PDF/wk/mm4812.pdf (accessed 2004 Oct 19).

12. England S, Loevinsohn B, Melgaard B, Kou U, Jha P. The evidence base for interventions to reduce mortality from vaccine-preventable diseases in low and middle-income countries [CMH working paper no WG5:10]. Commission on Macroeconomics and Health $(\mathrm{CMH}) ; 2001$. Available: www.cmhealth .org/docs/wg5_paper10.pdf (accessed 2004 Oct 13).

13. Dye C. Tuberculosis 2000-2010: control, but not elimination. Int 7 Tuberc Lung Dis 2000;(Suppl 4):S146-52.

14. Peto R, Baigent C. Trials: the next 50 years. Large scale randomised evidence of moderate benefits. BM7 1998;317:1170-1.

15. Nagelkerke NJ, Jha P, de Vlas SJ, Korenromp EL, Moses S, Blanchard JF, et al Modelling HIV/AIDS epidemics in Botswana and India: impact of interventions to prevent transmission. Bull World Health Organ 2002;80(2):89-96.

16. Daar AS, Thorsteinsdottir H, Martin DK, Smith AC, Nast S, Singer PA. Top ten biotechnologies for improving health in developing countries. Nat Genet 2002;32(2):229-32.

17. World Health Organization. Genomics and global bealth: report of the Advisory Committee on Health Research. Geneva: The Organization; 2002. Available: www .who.int/whosis/genomics/pdf/genomics_report.pdf (accessed 2004 Oct 13).

18. Land KM. The mosquito genome: perspectives and possibilities. Trends Parasitol 2003;19:103-5.

19. Weatherall DJ, Clegg JB. Genetic variability in response to infection: malaria and after. Genes Immun 2002;3:331-7.

20. Marra MA, Jones SJ, Astell CR, Holt RA, Brooks-Wilson A, Butterfield YS, et al. The Genome sequence of the SARS-associated coronavirus. Science 2003;300(5624):1399-404.

21. Jha P, Nagelkerke JD, Ngugi EN, Prasada Rao JV, Willbond B, Moses S, et al. Reducing HIV transmission in developing countries. Science 2001;292:224-5.

22. Nelson KE, Celentano DD, Eiumtrakol S, Hoover DR, Beyrer C, Suprasert $\mathrm{S}$, et al. Changes in sexual behavior and a decline in HIV infection among young men in Thailand. N Engl 7 Med 1996;335(5):297-303

23. Johnston R. Microbicides 2002: an update. AIDS Patient Care STDS 2002;16 (9):419-30.

24. Webby RJ, Webster RG. Are we ready for pandemic influenza? Science 2003; 302:1519-22

25. Laxminarayan R et al. Drug resistance. In: Jamison DT, Alleyne GA, Breman JG, Claeson M, Jha P, et al. Disease control priorities in developing countries. New York: Oxford University Press. In press.

26. Perrin L, Telenti A. HIV treatment failure: testing for HIV resistance in clinical practice. Science 1998;280:1871-3.

27. Hira SK, Panchal K, Parmar PA, Bhatia VP. High resistance to antiretroviral drugs: the Indian experience. Int 7 STD AIDS 2004;15(3):173-7.

28. De Vlas SJ, Nagelkerke NJ, Jha P, Plummer FA. Mother-to-child HIV transmission and ARVs. Science 2002 13;298(5601):2129.

29. Breman JG, Alilio MS, Mills A. Conquering the intolerable burden of malaria: what's new, what's needed: a summary. Am 7 Trop Med Hyg 2004;71 (2 Suppl):1-15.

30. Jamison DT, Sachs JD, Wang J. The effect of the AIDS epidemic on eco- nomic welfare in sub-Saharan Africa [CMH working paper no WG1:13] Commission on Macroeconomics and Health (CMH); 2001.

31. Fenner F, Henderson DA, Arita I, Jezek Z, Ladnyi ID. Smallpox and its eradication. Geneva: World Health Organization; 1998.

32. Bloom DE, Mahal A, Rosenberg L, Sevilla S, Steven D, Weston M. Asia's economies and the challenge of AIDS. Manila: Asian Development Bank; 2004

33. Copenhagen Consensus 2004. The top 10 challenges. Available: www.copenhagen consensus.com/Default.asp?ID=164 (accessed 2004 Oct 13).

34. Kumar R. Plague outbreak in 2001 in northern India. To be presented at Controlling the risk: science to combat global infectious diseases; Toronto; Nov 9-10, 2004.

35. World Health Organization. Global Forum for Health Research: the 10/90 report on health research 2001-2002. Geneva; The Organization: 2003.

36. Murphy KM, Topel RH, editors. The economic value of medical research. In: Measuring the gains of medical reseaerch: an economic approach. Chicago: University of Chicago; 2002. p. 41-73.

37. Klausner RD, Fauci AS, Corey L, Nabel GJ, Gayle H, Berkley S, et al. Medicine. The need for a global HIV vaccine enterprise. Science 2003;300:2036-9.

38. Varmus H, Klausner R, Zerhouni E, Acharya T, Daar AS, Singer PA. Public health. Grand challenges in global health. Science 2003;302:398-9.

39. Singh B. Innovations and challenges in funding rapid research responses to emerging infectious diseases: lessons learned from the outbreak of severe acute respiratory syndrome. Can 7 Infect Dis Med Microbiol 2004;15(3):167-70.

40. Maskalyk J. Medical journals and global medicine [editorial]. CMA7 2004;170 (1):65.

41. Cutler DM, Kadiyala S. The return to biomedical research: treatment and behavioral effects. In: Murphy KM, Topel RH, editors. Measuring the gains of medical research: an economic approach. Chicago: University of Chicago; 2002. p. 110-62.

42. Trends in developmental assistance. Organization for Economic Co-operation and Development (OECD); 2003. Available: www.oecd.org/dataoecd/42/21 /1860310.gif (accessed 2004 Oct 14)

43. Labbe AC, Patel S, Crandall I, Kain KC. A molecular surveillance system for global patterns of drug resistance in imported malaria. Emerg Infect Dis 2003;9 (1):33-6.

44. Fowke KR, Kaul R, Rosenthal KL, Oyugi J, Kimani J, Rutherford WJ, et al HIV-1-specific cellular immune responses among HIV-1-resistant sex workers. Immunol Cell Biol 2000;78(6):586-95.

45. Carter R, Mendis KN. Evolutionary and historical aspects of the burden of malaria. Clin Microbiol Rev 2002;15(4):564-94.

46. Mathers CD, Lopez A, Stein C, Ma Fat D, Rao C, Inoue M, et al. Deaths and disease burden by cause: global burden of disease estimates for 2001 by World Bank country groups. Washington (DC): World Bank; 2003. Available: www.fic.nih .gov/dcpp/wps/wp18.pdf (accessed 2004 Oct 19)

Correspondence to: Dr. Prabhat Jha, Centre for Global Health Research, St. Michael's Hospital, University of Toronto,

70 Richmond St. E, 2nd floor, Toronto ON M5C N8;

fax 416 864-5256; prabhat.jha@utoronto.ca

\section{Members of the Global IDEA Scientific Advisory Committee:}

Chair: Arthur S. Slutsky, St. Michael's Hospital, University of Toronto, Toronto, Ont. Members: Prabhat Jha, Centre for Global Health Research, St. Michael's Hospital, Department of Public Health Sciences and McLaughlin Centre for Molecular Medicine, University of Toronto (Conference Chair), Toronto, Ont.; Garry Aslanyan, Canadian International Developmental Agency, Ottawa, Ont.; Michel G. Bergeron, Infectious Disease Research Centre, Laval University, Ste-Foy, Que.; David Brown, Canadian Imperial Bank of Commerce, Toronto, Ont.; Robert Brunham, $B C$ Centre for Disease Control, Vancouver, BC; Dominic D’Alessandro, Manulife Financial, Manulife Financial, Toronto, Ont.; John Hunkin, Canadian Imperial Bank of Commerce, Toronto, Ont.; Kevin Kain, McLaughlin Centre for Molecular Medicine, University of Toronto, Toronto, Ont.; Judy Kopelow, Centre for Global Health Research, Toronto, Ont.; Donald E. Low, Mount Sinai Hospital, University of Toronto, Toronto, Ont.; Allison McGeer, Mount Sinai Hospital, University of Toronto, Toronto, Ont.; Nico Nagelkerke, Leiden University Medical Centre, Leiden, the Netherlands; and Francis A. Plummer, Health Canada National Microbiology Laboratory, Winnipeg, Man. 